\title{
Distribution of polychaetes in the shallow, sublittoral zone of Admiralty Bay, King George Island, Antarctica in the early and late austral summer
}

\author{
Letícia de Souza Barbosa ${ }^{1}$, Abílio Soares-Gomes ${ }^{1}$, Paulo Cesar Paiva ${ }^{2 *}$ \\ ${ }^{1}$ Department of Marine Biology, Fluminense Federal University, Niterói, Brazil; leticiadsb@gmail.com; abiliosg@vm.uff.br; \\ ${ }^{2}$ Department of Zoology, Federal University of Rio de Janeiro, Rio de Janeiro, Brazil; *Corresponding Author: paulo.paiva@gmail.com.
}

Received 20 July 2010; revised 25 August 2010; accepted 28 August 2010.

\begin{abstract}
This study assessed the spatial distribution pattern of soft-sediment polychaetes on the nearshore of Admiralty Bay, King George Island, Antarctica. In the early and late summer of 2003 104 , seven sites at three different depths $(20,30$ and 60 meters) were sampled using a van Veen grab. 8,668 individuals all told, belonging to 67 species and 23 families, were identified. The families Terebellidae, Syllidae and Maldanidae were the most speciose. Mean densities ranged from 45.2 to 388.1 ind. $0.1 \mathrm{~m}^{-2}$ in the early summer, and from 29 to 183 ind $.0 .1 \mathrm{~m}^{-2}$ in the late. The species Aphelochaeta cincinnata, Levinsenia gracilis and Rhodine antarctica were the most frequent and abundant. Initially, mean

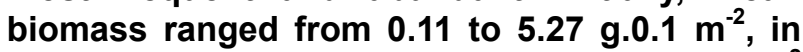
the early season and from 0.35 to $5.86 \mathrm{~g} .0 .1 \mathrm{~m}^{-2}$ towards the end. Aglaophamus trissophyllus, Eupolymnia sp. and Barrukia cristata were the species with the highest biomass. Polychaete taxocoenosis structure remained similar in both periods. In the early summer, mean densities, biomass and number of species were lower at 30 meters and higher at 60 , whereas in the late, these differences were higher among transects. Ice impacts, mainly anchor-ice, in the early summer, as well as icebergs later on, most likely caused the differences encountered.
\end{abstract}

Keywords: Polychaeta; Soft-Sediment; Benthic Structure; South Shetland Islands; Antarctic Peninsula

\section{INTRODUCTION}

The Antarctic benthos is characterized by pronounced endemism and a marked dependence on physical condi- tions, such as sediment patterns, waves and ice effects [1]. Distribution of the benthic community in shallow waters (up to $100 \mathrm{~m}$ ) could be influenced by depth [2]. According to Sahade et al. [3], benthic density is the highest at 25 meters. From here down to 50 meter depth, there is a decrease [4]. Below this, the community is free from the impacts of icebergs and storms, thereby reaching an advanced stage in development. Besides depth, distribution is also influenced by habitat heterogeneity, bottom topography and hydrodynamics, among other factors [2]. Low and stable water temperatures, low fluctuations in salinity during the summer, reduced terrigenous sediment input and the seasonality of food resources, could also exert an influence on both the structure and distribution of the Antarctic fauna [1]. Nevertheless, according to Barnes \& Conlan [5], ice remains as one of the foremost agents of disturbance in shallow water benthos.

The benthic fauna of the Southern Ocean is well known, the polychaetes being one of the most representative groups in soft-sediment habitats [6-8]. The group can account for over $50 \%$ of the macrofauna in several Antarctic areas, such as Chile Bay, Greenwich Island [9], Port Foster, Deception Island [10], Arthur Harbour, Anvers Island [11], McMurdo Sound [12] and Admiralty Bay, King George Island [6]. Polychaete composition and distribution in Admiralty Bay was already studied by several authors [6,13-19] and can be summarized in the following zonation patterns: the dominance of Leitoscoloplos kerguelensis, Ophryotrocha notialis and Microspio cf. moorei on shallow bottoms (down to $12 \mathrm{~m}$ ) and higher densities of Aphelochaeta cincinnata, Apistobranchus glacierae, Rhodine antarctica and Levinsenia gracilis further down. According to Conlan et al. [20], certain polychaetes, such as Ophryotrocha notialis, Capitella perarmata, Aphelochaeta sp. and Leitoscoloplos kerguelensis, are dominant in areas under the impact of sea-waste disposal, besides being capable of coloniz- 
ing ice-disturbed areas $[21,22]$.

The aim of this survey was to investigate polychaete spatial distribution in the nearshore soft-sediments at three depths in Admiralty Bay, during the early and late austral summer.

\section{STUDY AREA}

Admiralty Bay, the largest bay in King George Island, is approximately $122 \mathrm{~km}^{2}$, with depths exceeding 500 meters [23]. The fjord-like shaped bay has three inlets, Mackellar and Martel located in the northern portion, and Ezcurra located in the western [17]. The bay receives water from the Bransfield Strait through a 500meters-deep channel. Coarse sediments mixed with fine mud occur down to a depth of 50 meters, the rest consisting mainly of fine mud [24]. The sediment in front of the Brazilian Antarctic station contained high concentrations of trace metals $(\mathrm{B}, \mathrm{Mo}, \mathrm{Pb}, \mathrm{V}, \mathrm{Zn}, \mathrm{Ni}, \mathrm{Cu}, \mathrm{Mg}$ and $\mathrm{Mn})$, organic matter and oil contaminants. However, despite the evidence of contamination, the low bioavailability of these pollutants is an indication of low environmental risk [25]. Variation in temperature and salinity is slight, ranging from $-0.4^{\circ} \mathrm{C}$ to $0.9^{\circ} \mathrm{C}$ and 33.8 to 33.4 , respectively, at the bottom [24]. The phytoplankton from Admiralty Bay is dominated by diatoms, under the influence of benthic species from sediment resuspension or ice defrosting [26].

\section{MATERIAL AND METHODS}

Seven transects located in the Mackellar and Martel inlets were sampled (Figure 1): Research Station "Comandante Ferraz" (CFA, CFB and CFC), Botany Point (BP), Hennequin Point (HE), Machu Picchu (MP) and Thomas Point (AR), during the austral summer of 20032004. At each site, samples were collected at three depths $(20,30$ and 60 meters) with a van Veen grab $(0.056$

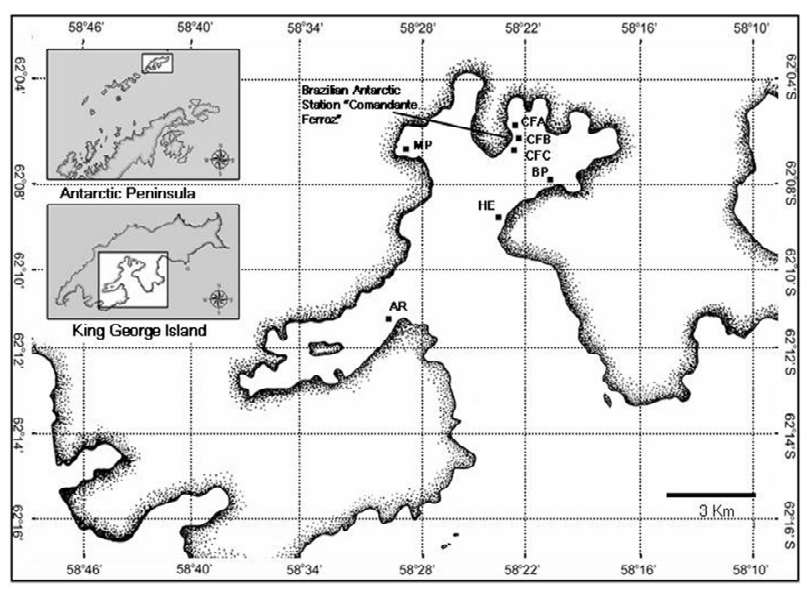

Figure 1. Sampling sites at Admiralty Bay. $\mathrm{m}^{2}$ ). In the early summer (November and December, 2003) three replicates were collected, whereas four were in the late season (February and March, 2004). Samples were sieved through a $0.5 \mathrm{~mm}$ mesh. Specimens were fixed in $4 \%$ formaldehyde and preserved in $70 \%$ alcohol. The polychaetes were identified at the species level. Unidentifiable individuals were included in the analysis as morphotypes. Biomass was estimated by the measurement of wet-weight $( \pm 0.01 \mathrm{mg})$. Dry-sieve and pipette methodologies were used for grain-size analysis, as described by Suguio [27]. Calcium carbonate content was determined by dry-weight difference after $\mathrm{HCl} \mathrm{10 \%}$ attack, and that of total carbon and nitrogen by using an Elemental Analyser CHNS/O Perkin Elmer (2400 Series II), with a detection limit of $0.02 \%$ for $\mathrm{C}$ and $0.03 \%$ for $\mathrm{N}$ [28]. Species densities (ind. $0.1 \mathrm{~m}^{2} \pm$ standard-error) were used to calculate species dominance, according to the formula:

$$
\mathrm{Do}=(\mathrm{Na} / \mathrm{N}) * 100
$$

where Do $=$ dominance of species $\mathrm{A}, \mathrm{Na}=$ density of species A and $\mathrm{N}=$ sum of all species densities.

Species occurrence frequencies were calculated by using the following formula:

$\mathrm{Fa}=(\mathrm{Pa} / \mathrm{P}) * 100$ where $\mathrm{Fa}=$ frequency of species $\mathrm{A}, \mathrm{Pa}=$ number of samples in which species A occurred, and $\mathrm{P}=$ total of samples.

Species with higher than $50 \%$ occurrence were considered constant, those between $50 \%$ and $10 \%$, common, and those with less than $10 \%$, rare. Density data were transformed (square root), and Two-way ANOVA employed to check differences between early and late summer surveys. Cluster analysis was with the UPGMA algorithm using a Bray Curtis similarity index calculated by densities. Diagrams of ordination were produced through non-metric Multi-Dimensional Scaling (nMDS) analysis. The significance of differences among depths during early and late summer was tested by One-Way Analysis of Variance by Similarities-ANOSIM [29].

Canonical Correspondence Analysis (CCA) was applied with a matrix of 10 abiotic variables (gravel, coarse sand, medium sand, fine sand, silt, clay, carbonate, total carbon, organic carbon and total nitrogen), together with the most frequent species in each of the summer periods. The transect AR $60 \mathrm{~m}$ was not considered, due to the lack of grain-size data. Statistical analysis was undertaken with the Statistica 6.0 program, multivariate analysis with the Primer 6, program, and CCA by using the Biplot 1.1 add-in routine for Excel [30].

\section{RESULTS}

\subsection{Abiotic Variables}

The sediment consisted mainly of silt and clay (more 
than $60 \%$ ) at most transects and depths, although the percentages of fine sand were higher (ca. 30\%) in some stations like HE and AR. At 60 meters, slightly lower percentages of both gravel and coarse sand were observed, when compared to shallower transects. Calcium carbonate content was slightly higher in the late summer (more than 12\%), whereas in the early season, this was lower at 20 and 30 meters, with the lowest $(6.5 \%)$ at MP. Carbon and nitrogen content were very low $(<1 \%)$. CFA, $\mathrm{CFB}$ and $\mathrm{CFC}$ presented the highest percentages of carbon content $(0.54 \%$ to $0.75 \%)$, and MP the lowest $(0.28 \%$ to $0.46 \%$ ). There was no apparent variation of either variable with the increase in depth.

\subsection{Polychaete Composition}

A total of 8,668 individuals were collected throughout the period. The set of samples yielded 67 species and four morphotypes (Cirratulidae gen. sp.1, Cirratulidae gen. sp.2, Maldanidae gen. sp. and Terebellidae gen. sp.), belonging to 23 families (Table 1). 21 species were collected in each sampling survey. The most speciose families were Terebellidae and Syllidae with seven species each, and Maldanidae with six. The families Glyceridae and Sabellidae were exclusive to the early summer, whereas Nereididae and Serpulidae were to the late summer. The families Nereididae, Serpulidae and Glyceridae were each represented by only one species, viz., Nicon ehlersi, Helicosiphon biscoensis and Glycera capitata, respectively. The sabellids were represented by three species: Euchone pallida, Perkinsiana litorallis and Perkinsiana milae, all somewhat scarce during the summer.

\subsection{Dominance and Frequency}

In terms of density, the species Aphelochaeta cincinnata, Levinsenia gracilis, Cirratulidae gen. sp. 1, Apistobranchus glacierae and Rhodine antarctica dominated, throughout the whole period studied. The exceptions were Cirratulidae gen. sp. 1 and $A$. glacierae, dominant only at the beginning. Throughout, Aphelochaeta cincinnata was the most frequent species, with $93.55 \%$ in the early summer and $85.71 \%$ in the late. The species Levinsenia gracilis and Rhodine antarctica were also constant during the whole study period, with $69.35 \%$ and $56.45 \%$, respectively, in the first part, and both $65.48 \%$ towards the end. These three species were responsible for $33.7 \%$ of total polychaetes in the early summer and $34.7 \%$ in the late. Aricidea (Acmira) strelzovi, Leitoscloplos geminus, Brada villosa, Apistobranchus glacierae, Barrukia cristata and Cirrophorus brevicirratus were considered common throughout. Scalibregma inflatum, besides being a low-frequency species during the whole period $(8.06 \%$ in the early part and $5.95 \%$ in the late), occurred only at 60 meters (Table 1).

\subsection{Density and Biomass}

Polychaete density ranged from 45.24 to 388.10 ind. $0.1 \mathrm{~m}^{-2}$ in the early summer. Apistobranchus glacierae, with the highest score all told, was also responsible for the high result observed at CFC (20 m) (173.21 \pm 76.79 ind. $0.1 \mathrm{~m}^{-2}$ ). The species Aphelochaeta cincinnata at CFB $(60 \mathrm{~m})$, Rhodine antarctica at CFC $(20 \mathrm{~m})$ and Levinsenia gracilis at CFC $(60 \mathrm{~m})$ also presented high values (Figure 2). In the late summer, polychaete density varied from 29.02 to 183.93 ind. $0.1 \mathrm{~m}^{-2}$. The highest densities, attributed to $R$. antarctica, were observed at the MP transect at 20 and 30 meters (Figure 3).

During sampling, a significant variation in density among depths was observed (ANOVA, $p<0.002$ ) (Table 2), with lower densities at 30 meters when compared to both 20 and 60 (Tukey test, $\mathrm{p}<0.005$ ), although no differences among transects were detected $(p=0.599)$. Nevertheless, this pattern seems to be rather complex, since the interaction between transect and depth was significant $(\mathrm{p}<0.02)$. This interaction occurred at transects CFA and CFC, with no clear bathymetric pattern. On the contrary, in late summer, significant differences were found only among transects $(p<0.002)$, but not depths (Table 2), with MP and AR presenting higher densities than CFA and CFC (Tukey test, p $<0.05$ ). These differences occurred due to the high densities of cirratulids (Aphelochaeta cincinnata and Cirratulidae gen. sp.1), paraonids (Levinsenia gracilis, Aricidea (Acmira) strelzovi and Cirrophorus brevicirratus) and the maldanid Rhodine antarctica, at MP and AR. On the other hand, biomass encountered at both CFA and CFC was low. Surprisingly, polychaete density at CFB was similar to that observed at MP and AR.

In the early summer, biomass means ( \pm standard-error) ranged from $5.27 \pm 4.19$ g. $0.1 \mathrm{~m}^{-2}$ at CFC- $20 \mathrm{~m}$, to 0.11 \pm 0.06 g. $0.1 \mathrm{~m}^{-2}$ at BP-30 m (Figure 4). In the late season, the highest biomass mean was observed at CFB-30 $\mathrm{m}\left(5.86 \pm 4.72\right.$ g. $\left.0.1 \mathrm{~m}^{-2}\right)$ and the lowest at BP-30 m $\left(0.35 \pm 0.27\right.$ g. $\left.0.1 \mathrm{~m}^{-2}\right)$ (Figure 5). The species Aglaophamus ornatus, Eupolymnia sp. and Barrukia cristata presented the highest values. Although Rhodine antarctica biomass was not high, it remained constant at MP, all through the later part of summer, this constancy probably contributing to the proximity of values found at all depths.

\subsection{Multivariate Analysis}

In the early summer, the samples were grouped through cluster analysis, according to depth. The results indicated that in the first group, composed of transects $\mathrm{MP}, \mathrm{BP}, \mathrm{AR}$ at 20 meters, and MP and AR at 30 meters, 
Table 1. Frequency (Fo) and dominance (Do) of polychaete species in early and late summer, and species codes used in canonical correspondence analysis.

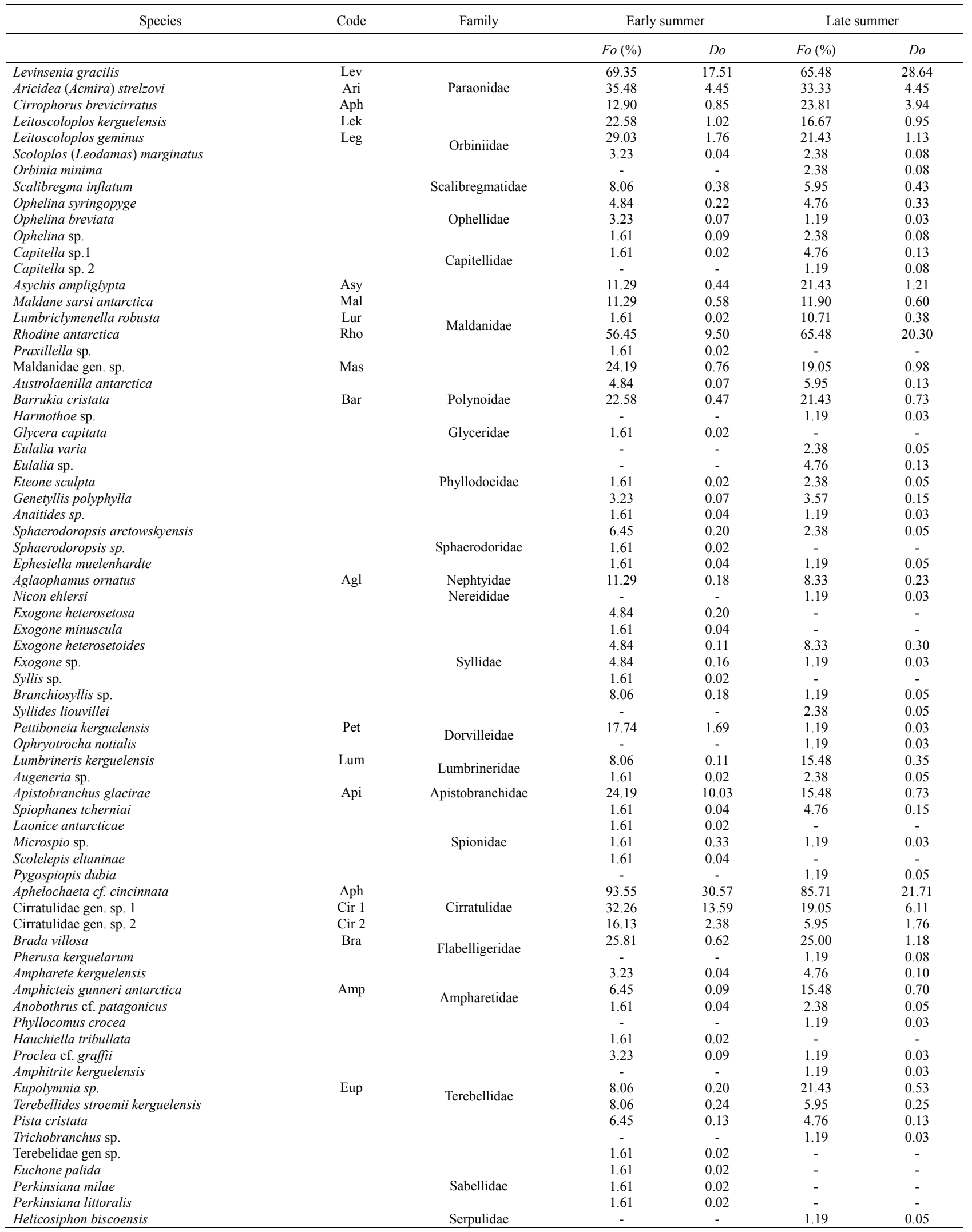




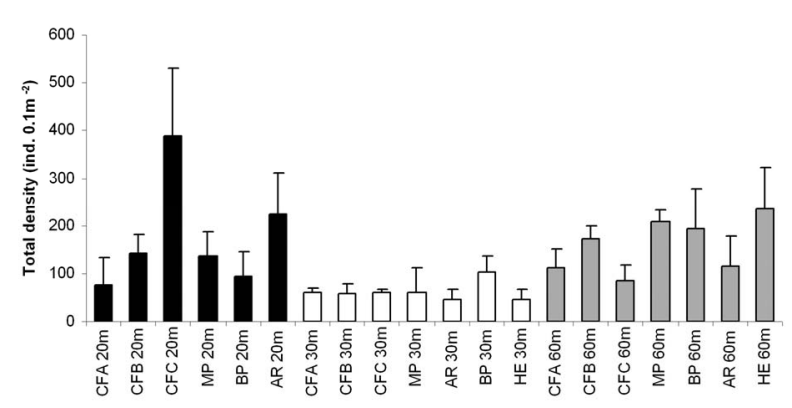

Figure 2. Mean densities ( \pm stardard-error) of Polychaeta at the transects in early summer. Depths: $20 \mathrm{~m}=$ black bars; $30 \mathrm{~m}=$ white bars; $60 \mathrm{~m}=$ gray bars.

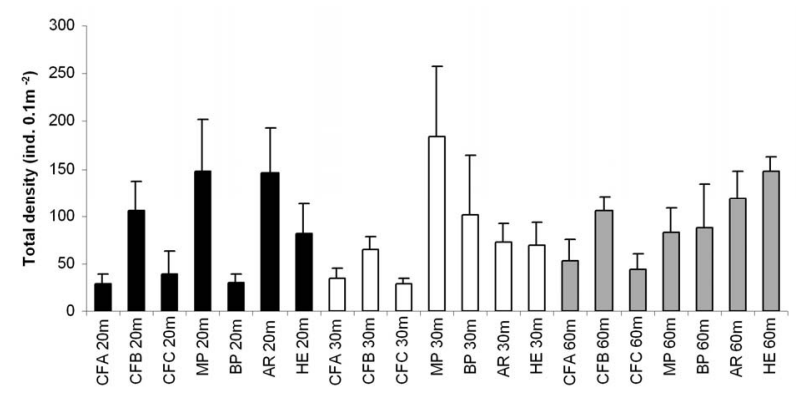

Figure 3. Mean densities ( \pm stardard-error) of Polychaeta at the transects in late summer. Depths: $20 \mathrm{~m}=$ black bars; $30 \mathrm{~m}=$ white bars; $60 \mathrm{~m}=$ gray bars.

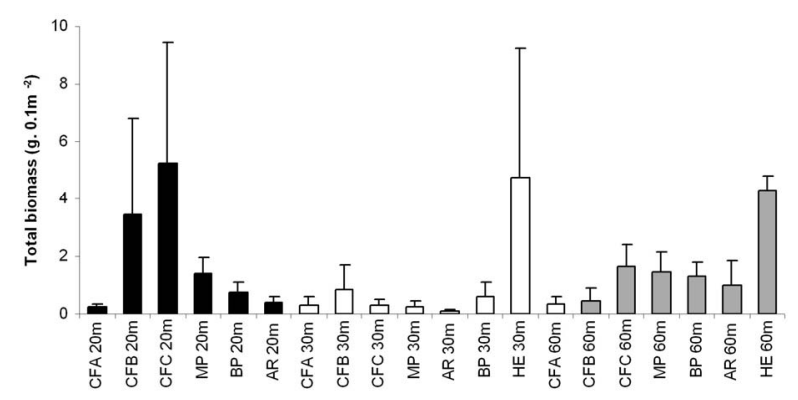

Figure 4. Mean biomass ( \pm stardard-error) of Polychaeta at the transects in early summer. Depths: $20 \mathrm{~m}=$ black bars; $30 \mathrm{~m}=$ white bars; $60 \mathrm{~m}$ = gray bars.

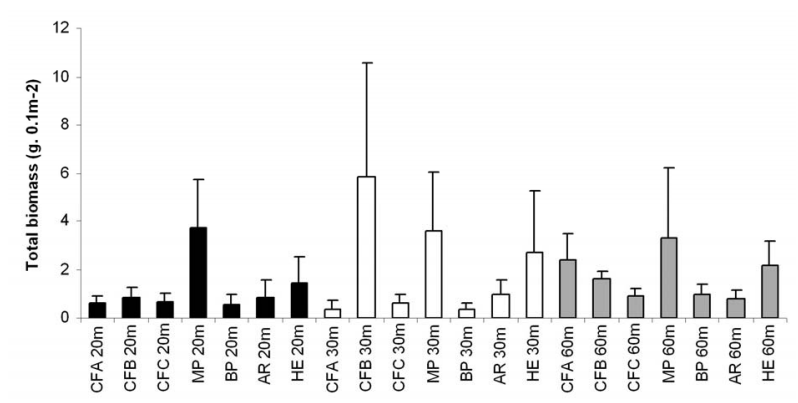

Figure 5. Mean biomass ( \pm stardard-error) of Polychaeta at the transects in late summer. Depths: $20 \mathrm{~m}=$ black bars; $30 \mathrm{~m}=$ white bars; $60 \mathrm{~m}=$ gray bars.
Table 2. Results of Two-way ANOVA in early and late summer.

\begin{tabular}{ccccc}
\hline Factors & & Early summer & \multicolumn{2}{c}{ Late summer } \\
\hline & $p$ & $\mathrm{~F}$ & $p$ & $\mathrm{~F}$ \\
\cline { 2 - 5 } Transect & 0.599 & 0.737 & 0.001 & 4.286 \\
Depth & 0.001 & 11.716 & 0.581 & 0.547 \\
Transect * Depth & 0.015 & 1.554 & 0.583 & 0.867 \\
\hline
\end{tabular}

the density of Cirratulidae gen. sp. 1 was high, whereas both Branchiosyllis sp. and $S$. arctowskyensis were absent. In the second group (CFB and CFC at $20 \mathrm{~m}, \mathrm{HE}$ at $30 \mathrm{~m}$, and $\mathrm{MP}$ and $\mathrm{HE}$ at $60 \mathrm{~m}$ ), both $R$. antarctica and $A$. glacirae were the most abundant. In the third group, formed by CFA at 20 meters, and CFA, CFB, CFC and $\mathrm{BP}$, all at 30 meters, richness and densities were low in $R$. antarctica, $A$. amphiglypta and $A$. cincinnata. In the last group, A. cincinnata, L. gracilis and Cirratulidae gen. sp. 2 were abundant, and both $S$. inflatum and $A$. strelzovi present (Figure 6). The results from cluster analysis were confirmed through nMDS. In the late summer, no clear pattern of clustering, in relation to either transects or depths, was apparent.

When using ANOSIM, no differences were detected in the polychaete community between the periods sampled $(\mathrm{R}$ global $=0.031 ; \mathrm{p}=20.5 \%)$, although the contrary was the case as regards depths. In the early summer, communities at 60 meters differed from those found at 20 and 30 meters, whereas in the late season, the only difference was between 20 and 60 meters (Table 3).

Results through Canonical Correlation Analysis (CCA) were rather similar, in both early and late summer. The first axis was responsible for $45.9 \%$ of the variance in early summer and $42.8 \%$ in late and was positively related to gravel, coarse and fine sand and negatively so to silt, clay, carbonate, carbon and nitrogen contents. The sediment in all transects at 20 meters was coarser, whereas that at 60 meters was characterized by the dominance of silt and clay fractions, and that at $30 \mathrm{me}-$ ters an intermediate pattern between the former two. The second axis accounted for $25.5 \%$ and $20.8 \%$ of the variance in early and late summer, respectively (Figures 7 and 8). In both summer periods, most species appeared to be associated with gravel, and coarse and fine sand. The maldanids Maldane sarsi antarctica and Asychis amphiglypta were related to stations at 60 meters. The species L. geminus, L. kerguelensis, A. glacirae and $C$. brevicirratus and Cirratulidae gen sp. 1 were positively related with gravel, and coarse and fine sand.

\section{DISCUSSION}

The number of polychaete species found in the present study was higher than that presented by Sicinski \& Ja- 
(a)
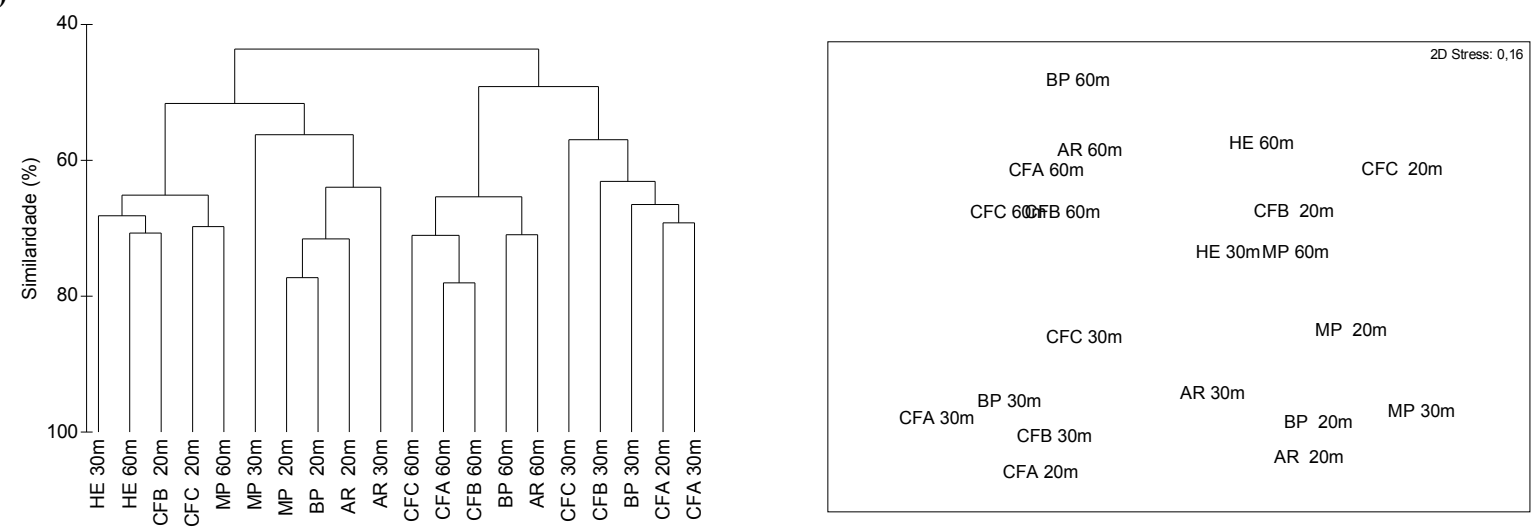

(b)
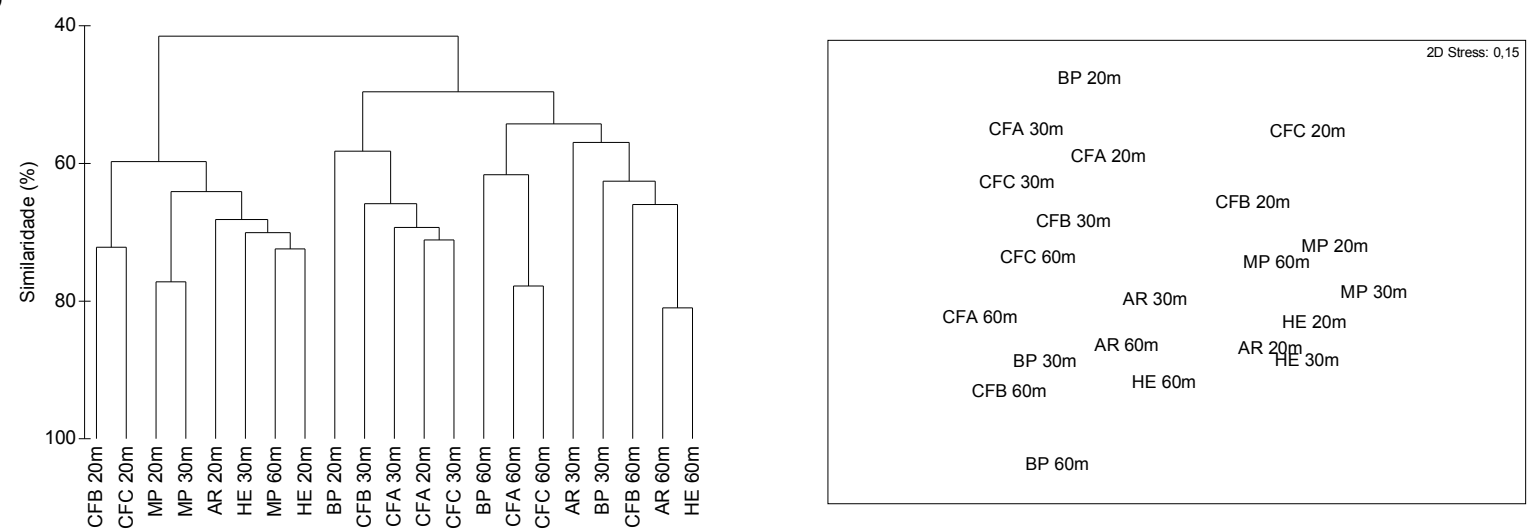

Figure 6. Cluster analysis and nMDS from the transects. (a) polychaete density in early summer; (b) polychaete density in late summer.

Table 3. Results of One-way ANOSIM for effect of depth (20, 30 and $30 \mathrm{~m}$ ) on polychaete abundance data.

\begin{tabular}{ccccc}
\hline & \multicolumn{2}{c}{ Early summer } & \multicolumn{2}{c}{ Late summer } \\
\cline { 2 - 5 } Groups & R-value & $\begin{array}{c}\text { Significance } \\
\text { level (\%) }\end{array}$ & R-value & $\begin{array}{c}\text { Significance } \\
\text { level (\%) }\end{array}$ \\
\hline All depths & 0.43 & 0.1 & 0.25 & 1.8 \\
20,30 & 0.21 & 8.2 & 0.15 & 11.1 \\
20,60 & 0.60 & 0.1 & 0.48 & 0.3 \\
30,60 & 0.49 & 0.1 & 0.13 & 13.7 \\
\hline
\end{tabular}

nowska [16] and Bromberg [17], in Admiralty Bay, at similar depths. However, this richness was low when compared with that in other Antarctic areas, such as Arthur Harbor on Anvers Island [31], Chile Bay on Greenwich Island [32], Terra Nova Bay [33], Livingston Island and Port Foster on Deception Island [34], the Weddell Sea continental shelf and slope, and the Antarctic Peninsula [35]. The relatively low richness found in the present study might be related to differences in sampling effort, seeing that in the aforementioned studies, different sampling techniques were used. The dominance of Aphelochaeta cincinnata is in accordance with the results obtained by Sicinski [6], Gambi et al. [33] and Bromberg [17]. The high density of Rhodine antarctica

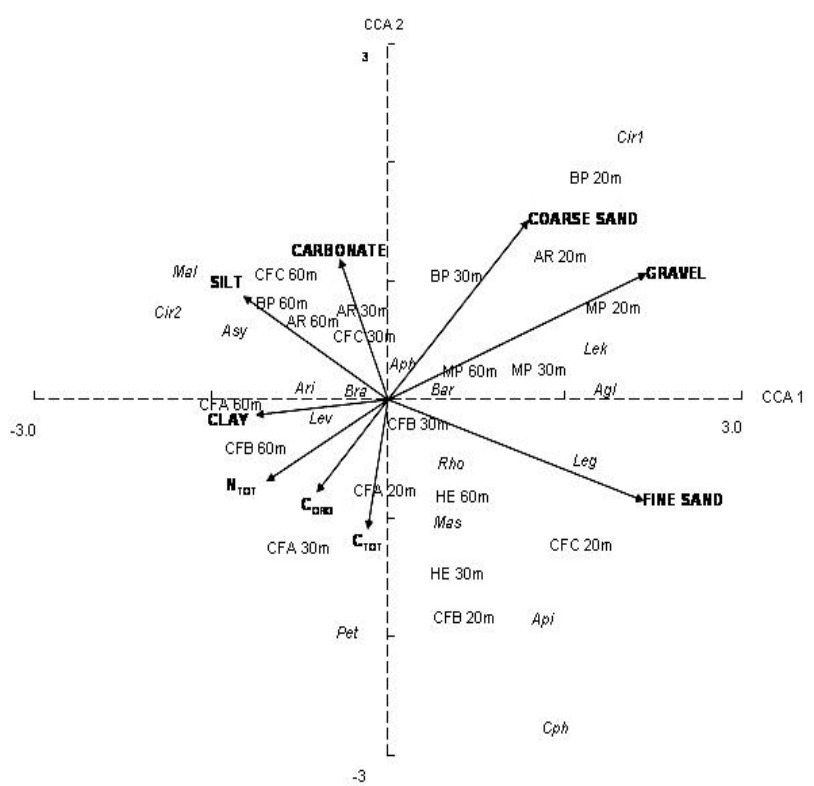

Figure 7. Graphic representation of the two axis of canonical correspondence analysis for early summer. For species codes see Table 1. 


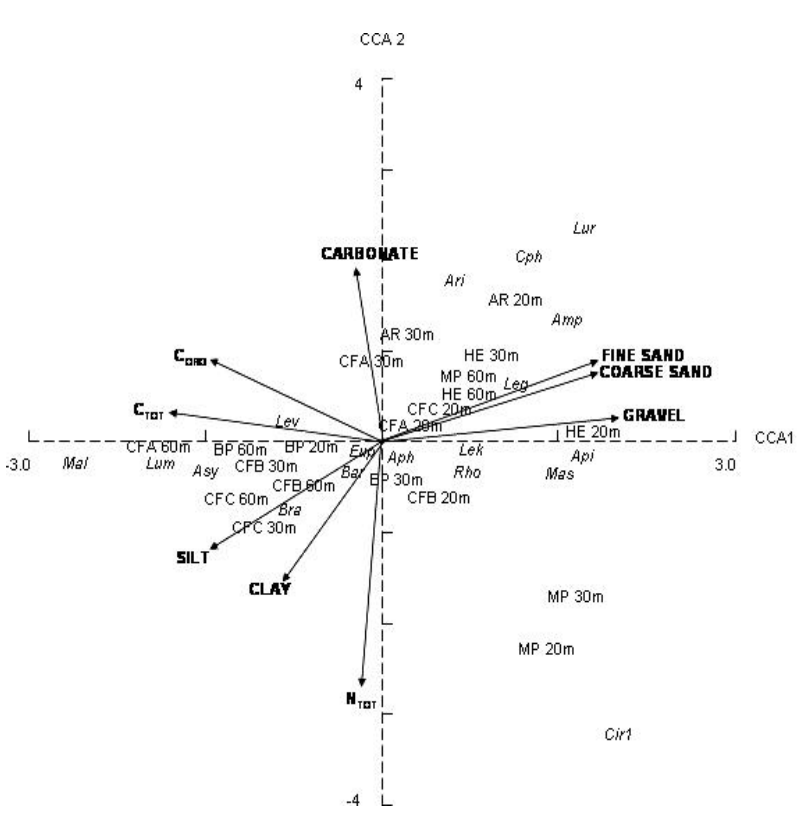

Figure 8. Graphic representation of the two axis of canonical correspondence analysis for late summer. For species codes see Table 1 .

at the MP transect could be related to its life cycle. According to Dayton \& Oliver [12], in McMurdo Sound, the individuals of the family Maldanidae may have evolved asexual reproduction in response to high predation and juvenile mortality. The dominance of maldanids was also reported by Gallardo et al. [9], who found a benthic community dominated by Maldane sarsi antarctica (Maldane assembly) in Chile Bay. Jazdzewski et al. [24] and Sicinski [6,13] also observed typical maldanid communities at depths over 100 meters.

The highest mean density observed in the early summer was similar to that reported by Sicinski [14]. On the other hand, mean density itself, although in accordance to that observed by Sicinski \& Janowska [16], was lower than that reported by other authors [17,33-35]. These differences may reflect variations in sampling design, depth and seasonality. The mean values of biomass were similar to those observed in Admiralty Bay by Sicinski \& Janowska [16], and were within the range reported by Gambi et al. [33]. According to Sicinski [13], polychaete biomass at $50 \mathrm{~m}$ may vary from 30 to $40 \mathrm{~g} \cdot \mathrm{m}^{-2}$ and might be responsible for $15 \%$ of the local zoobenthic biomass itself. The species responsible for the increase in biomass values, Aglaophamus ornatus and Eupolymnia sp. occurred mainly at 20 and 30 meters, respectively. This may be related to the deposition of organic matter from phytoplankton bloom, which occurs in the early summer [36].

Polychaete taxocoenosis structure remained the same throughout the period under study, possibly as a result of the prevailing sedimentary conditions (grain-size percentages) remaining invariable between transects. Nevertheless, certain differences were observed during the early and late summer, separately. During the early summer, polychaete mean density, biomass and richness declined at the 30 meters level and increased at the 60 . An increase in density related to depth had been previously reported in the Martel inlet [16]. The results in early summer may be an outcome of ice impact. According to Sahade et al. [3], ice impacts (icebergs and anchor-ice) seem to be the major regulating factor of benthic assemblages in shallow waters. Although actually not observed in this study, but based mainly on underwater observations, anchor-ice impacts have been imputed as promoting winter structuring in benthic communities. The displacement of established fauna in their area of influence may be attributed to these phenomena, thereby accounting for the low diversity in early summer [37]. According to Dayton et al. [38], the influence of anchor-ice impacts extends down to 33 meters, thus constituting the main cause of low diversity in shallow waters. Anchor-ice usually occurs during the winter, but its influence might have extended throughout the early summer of 2003/04, with consequential superficial sediment defaunation, thus making it difficult for the community to recover within a few months.

The increase in temperature in the late summer promotes the formation of icebergs. Echeverría \& Paiva [39] reported the presence of one in the summer of 2001 at the CFB 25 meter station, where it remained for over 20 days. Iceberg impacts are likely to affect benthic communities down to 20 meters. Below this, conditions are more stable, with higher densities, biomass and richness, the area below 30 meters thus presenting a substantial change in benthic megafauna structure, composition and diversity [37]. In both summer periods, most of the species which appear to be related to coarser sediment fractions are motile or discretely motile polychaetes. On the other hand, the maldanids (sessile polychaetes) related to higher percentages of silt and clay, appear mostly at 60 meters. Further analysis of polychaete feeding guilds is necessary to better evaluate their distribution in Admiralty Bay.

The possible environmental impacts related to activeties of the Brazilian research station (Cmte. Ferraz) were not revealed in this survey, since variability among those transects under the influence of the station itself (CFA, CFB and CFC) was higher than among all the others. Furthermore, the slight variation between early and late summer seems to be more related to natural impacts than to the more intense activities at the research station itself. 


\section{ACKNOWLEDGEMENTS}

The authors would like to thank the staff of the Brazilian Antarctic Station "Comandante Ferraz" and the Brazilian Antarctic Programm (PROANTAR) for logistical support, Laboratorio de Ciências Ambientais/UENF for the abiotic data, Lucia Campos (GEAMB/UFRJ) for providing biological material, and Rafael Moura for the map. This work was supported by grant from CNPq/MCT/MMA (PROANTAR), and a MSC fellowship from Coordenadoria de Aperfeiçoamento de Pessoal de Nível Superior (CAPES) for first author and research fellowships from Conselho Nacional de Desenvolvimento Científico e Tecnológico $(\mathrm{CNPq})$ for second and third author.

\section{REFERENCES}

[1] Arntz, W.E., Brey, T. and Gallardo, V.A. (1994) Antarctic zoobenthos. Oceanography and Marine Biology - An Annual Review, 32, 241-304.

[2] Clarke, A. (1996) The distribution of Antarctic marine benthic communities. In: Ross, R.M., et al. Eds., Foundations for Ecological Research West of the Antarctic Peninsula. Antarctic Research Series, 70, 219-230.

[3] Sahade, R., Tatian, M., Kowalke, J., Kuhne, S. and Esnal, G.B. (1998) Benthic faunal associations on soft substrates at Potter Cove, King George Island, Antarctica. Polar Biology, 19(2), 85-91.

[4] Parulekar, A.H., Ansari, Z.A. and Harkantra, S.N. (1983) Benthic fauna of the Antarctic Ocean: Quantitative aspects. In: Iyenger, R.V. and Rajaram, R., Eds., Scientific Report of First Indian Expedition to Antarctica, Department of Ocean Development, New Delhi, 213-218.

[5] Barnes, D.K.A. and Conlan, K.E. (2007) Disturbance, colonization and developmentof Antarctic benthic communities. Philosophical Transactions of the Royal Society $B$, 362(1477), 11-38.

[6] Sicinski, J. (1986) Benthic assemblages of polychaeta in chosen regions of Admiralty Bay (King George Island, South Shetlands Island). Polish Polar Research, 7(1-2), 63-78.

[7] Arnaud, P.M., Jazdzewski, K., Presler, P. and Sicinski, J. (1986) Preliminary survey of benthic invertebrates collected by Polish Antarctic Expeditions in Admiralty Bay, King George Island, South Shetland Islands, Antarctica. Polish Polar Research, 7(1-2), 7-24.

[8] Clarke, A. and Johnston, N.M. (2003) Antarctic marine benthic diversity. Oceanography and Marine Biology: An Annual Review, 41, 47-114.

[9] Gallardo, V.A., Castillo, J.C., Retamal, A.Y., Moyano, H. I. and Hermosilla, J.G. (1977) Quantitative studies on the soft-bottom macrobenthic animal communities of shallow Antarctic Bays. In: Llano, G.A. Ed., Adaptations within Antarctic Ecosystems, Gulf Publishing, Houston, 361-387.

[10] Retamal, M.A., Quintana, R. and Neira, E. (1982) Analisis cualiy cuantitativo de las comunidades bentonicas en Bahia Foster (Isla Decepción) (XXXV Expedición Antartica Chilena, enero 1981). Série Cientifica Instituto Antártico Chileno, 29, 5-15.

[11] Lowry, J.K. (1975) Soft bottom macrobenthic commu- nity of Arthur Harbor, Antarctica. Antarctic Resesarch Series, 23(1), 1-19.

[12] Dayton, P.K. and Oliver, J.S. (1977) Antarctic soft-bottom benthos in oligotrophic and eutrophic environments. Science, 197(4298), 55-58.

[13] Sicinski, J. (1993) Polychaeta. In: Racuksa-Suszczewski, S. Ed., The Maritime Antartic Coastal Ecosystem of Admiralty Bay, Department of Antarctic Biology, Polish Academy of Sciences, Warsaw, 101-107.

[14] Sicinski, J. (2000) Polychaeta (Annelida) of Admiralty Bay: Species richness, diversity, and abundance. Polish Polar Research, 21(3-4), 153-169.

[15] Wägele, J.W. and Brito, T.A.S. (1990) Die sublitorale fauna der maritimen Antarktis, Erste unterwasserbiobachtungen in der Admiralitasbucht. Natur und Museum, 120(7), 269-282.

[16] Sicinski, J. and Janowska, E. (1993) Polychaetes of the shallow sublittoral of Admiralty Bay, King-George Island, South Shetland Islands. Antarctic Science, 5(2), 161-167.

[17] Bromberg, S., Nonato, E.F., Corbisier, T.N. and Petti, M.A.V. (2000) Polychaetes distribution in the nearshore zone of Martel Inlet, Admiralty Bay (King George Island, Antarctica). Bulletin of Marine Science, 67(1), 175-188.

[18] Echeverría, C.A., Paiva, P.C. and Alves, V.C. (2005) Composition and biomass of shallow benthic megafauna during an annual cycle in Admiralty Bay, King George Island, Antarctica. Antarctic Science, 17(3), 312-318.

[19] Petti, M.A.V., Nonato, E.F., Skowronski, R.S.P. and Corbisier, T.N. (2006) Bathymetric distribution of the meiofaunal polychaetes in the nearshore zone of Martel intel, King George Island, Antarctica. Antarctic Science, 18(2), 163-170.

[20] Conlan, K.E., Kim, S.L., Leninhan, H.S. and Oliver, J.S. (2004) Benthic changes during 10 years of organic enrichment by McMurdo Station, Antarctica. Marine Pollution Bulletin, 49(1-2), 43-60.

[21] Conlan, K.E., Leninham, H.S., Kvitek, R.G. and Oliver, J.S. (1998) Ice scour disturbance to benthic communities in the Canadian high arctic. Marine Ecology Progress Series, 166(1), 1-16.

[22] Gerdes, D., Hilbig, B. and Montiel, A. (2003) Impact of iceberg scouring on macrobenthic communities in the high-Antarctic Weddell Sea. Polar Biology, 26(5), 295301.

[23] Lipski, M. (1987) Variations of physical conditions, nutrients and chlorophyll a content in Admiralty Bay (King George, South Shetland Islands, 1979). Polish Polar Research, 8(4), 307-332.

[24] Jazdzewski, K., Jurasz, W., Kittel, W., Presler, E., Presler P. and Sicinski, J. (1986) Abundance and biomass estimates of the benthic fauna in Admiralty Bay, King George Island, South Shetland Islands. Polar Biology, 6(1), 5-16.

[25] Santos, I.R., Silva-Filho, E.V., Schaefer, C.E.G.R., Albuquerque-Filho, M.R. and Campos, L.S. (2005) Heavy metal contamination in coastal sediments and soils near the Brazilian Antarctic Station, King George Island. $\mathrm{Ma}$ rine Pollution Bulletin, 50(2), 185-194.

[26] Lange, P.K., Tenenbaum, D.R., Braga, E.S. and Campos, L.S. (2007) Micro phytoplankton assemblages in shallow waters at Admiralty Bay (King George Island, Antarctica) during the summer 2002-2003. Polar Biology, 30(11), 
$1438-1492$.

[27] Suguio, K. (1973) Introdução à sedimentologia. Editora da Universidade de São Paulo, São Paulo, 317.

[28] Skoog, D.A. and Leary, J.J. (1992) Principles of instrumental analysis. 4th Edition, Saunders College Publishing, Forth Worth, 801.

[29] Clarke, K.R. and Warwick, R.W. (1994) Change in marine communities: An aproach to statistical analysis and interpretation. Plymouth Marine Laboratory, Bourne Press, Bournemouth.

[30] Lipkovich, I. and Smith, E.P. (2002) Biplot and singular value decomposition macros for Excel. Journal of Statistical Software, 7(5), 1-15.

[31] Richardson, M.D. and Hedgpeth, J.W. (1977) Antarctic soft-bottom macrobenthic community adaptations to a cold stable, highly, productive, glacially affected environment. In: Llano, G.A., Ed., Adaptations within Antarctic Ecosystems, Gulf Publishing, Houston, 181-196.

[32] Gallardo, V., Medrano, S.A. and Carrasco, F.D. (1988) Taxonomic composition of the sublittoral soft-bottom polychaetes of Chile Bay (Greenwich Island, South Shetland Islands, Antarctica). Serie Cientifica Instituto Antártico Chileno, 37(1), 49-67.

[33] Gambi, M.C., Castelli A. and Guizzardi, M. (1997) Polychaete populations of the shallow soft bottoms off Terra Nova Bay (Ross Sea, Antarctica): Distribution, diversity and biomass. Polar Biology, 17(3), 199-210.
[34] San Martin, G., Parapar, J., García, F.J. and Redondo, M.S. (2000) Quantitative analysis of soft-bottoms infaunal macrobenthic polychaetes from South Shetland Islands (Antarctica). Bulletin of Marine Science, 67(1), 83102.

[35] Hilbig, B., Verdes, D. and Montiel, A. (2006) Distribution patterns and biodiversity in polychaete communities of the Weddell Sea and Antarctic Peninsula area (Southern Ocean). Journal of Marine Biological Association of the U.K., 86(4), 711-725.

[36] Mincks, S. and Smith, C.R. (2007) Recruitment patterns in Antarctic Peninsula shelf sediments: Evidence of decoupling from seasonal phytodetritus pulses. Polar Biology, 30(5), 587-600.

[37] Nonato, E.F., Brito, T.A.S., Paiva, P.C., Petti, M.A.V. and Corbisier, T.N. (2000) Benthic megafauna of the nearshore zone of Martel Inlet (King George Island, South Shetland Islands, Antarctica): Depth zonation and underwater observations. Polar Biology, 23(8), 580-588

[38] Dayton, P.K., Robilliard, G.A., Paine, R.T. and Dayton, L. B. (1974) Biological accommodation in the benthic community at McMurdo Sound, Antarctica. Ecological Monographs, 44(1), 105-128.

[39] Echeverría, C.A and Paiva, P.C. (2006) Macrofaunal shallow benthic communities along a discontinuous annual cycle at Admiralty Bay, King George Island, Antarctica. Polar Biology, 29(3), 263-269. 